\title{
Paying Minorities to Leave
}

\section{Mollie Gerver}

This paper received a 'Revise and Resubmit' from Politics, Philosophy and Economics. A final decision is scheduled for February 2017.

Over fifty years ago in New Orleans, white segregationists gave cash and transport to African-Americans agreeing to move to New York City. ${ }^{1}$ In a recent case in New York, a landlord paid black tenants $\$ 12,000$ to leave their apartments, increasing the value of the property as only white tenants remained. ${ }^{2}$ In a campaign proposal in 2010, the British National Party promised to pay $\$ 78,000$ to each non-white resident who agreed to voluntarily leave the country and never return. ${ }^{3}$ In theory, a family of six could receive half a million dollars to move to Somalia, Ethiopia, or Iraq.

Is it morally permissible to pay minorities to leave?

When we think of wrongful discrimination, we often imagine a victim's options constrained. Victims are denied jobs, visas, apartments, places in universities, and equal rights before the law. ${ }^{4}$ Rarely do we imagine victims receiving more options because they are not wanted. At most, we imagine them receiving the same number of options, as when children are segregated into separate schools. When minorities are paid to leave, receiving an option unavailable to others, it remains unclear whether such offers are morally permissible.

When I write that it is not clear if such offers are permissible, I do not claim that scholars ignore cases of discrimination where individuals benefit. Deborah Hellman

\footnotetext{
${ }^{1}$ Clive Webb. 2004. "'A Cheap Trafficking in Human Misery': The Reverse Freedom Rides of 1962," Journal of American Studies 38(2):249-271.

${ }^{2}$ DW Gibson. 2015. “'I Put in White Tenants': The Grim, Racist (and Likely Illegal) Methods of One Brooklyn Landlord," New York Magazine 12/5.

${ }^{3}$ Jon Smith. 2010. "BNP would offer $£ 50,000$ to leave the country," The Independent, 29/4.

${ }^{4}$ Kasper Lippert-Rasmussen. 2013. Born Free and Equal? A Philosophical Inquiry into the Nature of Discrimination. Oxford: Oxford University Press; Shlomi Segall. 2012. "What's so Bad about Discrimination?" Utilitas 24(1): 82-100.
} 
discusses such cases, including one involving the US Food and Drug Administration marketing a specific heart medication to African-Americans, statistically more likely to benefit from the drug. Advertising in this manner, she suggests, may reinforce the false belief that races are biologically distinct from each other. But in these cases, Hellman concludes, the government can avoid this harm by emphasizing that African-Americans are not a biologically distinct group of people. ${ }^{5}$ No disclaimer is at hand when minorities are paid to leave in order to exclude them. The benefit arises precisely because of racism; had the payer not been racist, there would be no monetary offer at all. If there were no monetary offer, then some minorities would be worse off.

In the next section I will argue that current theories of discrimination cannot quite establish whether paying minorities to leave is all-things-considered impermissible, given the benefits to the recipients. In Sections 2 I argue that payments are impermissible, and ought to be banned, if they demean or harm other members of society who do not benefit. In Section 3 I will consider when such payments ought to be outlawed. I will address the concern that, in banning such payments, states are undermining the liberty of minorities who wish to accept these payments.

Before proceeding, a brief note on my assumptions and limitations.

I shall generally use the term "discrimination" in its non-normative sense to describe any differential treatment. My goal is to consider whether paying minorities to leave is the type of differential treatment that is morally permissible.

I shall assume that an act can be permissible even if wrong in some ways. ${ }^{6}$ When I write "wrong in some ways" I mean there are ethical reasons to avoid the act, even if there are countervailing reasons to partake in the act. When I write "permissible" I mean that, because these countervailing reasons are especially weighty, individuals

\footnotetext{
${ }^{5}$ Deborah Hellman. 2008. When Is Discrimination Wrong? Cambridge, MA: Harvard University Press: 67

${ }^{6}$ More generally, I assume that an act can be morally permissible even if wrong. See Julia Driver. 1992.

"The Suberogatory", Australasian Journal of Philosophy, 70: 286-295.
} 
are morally permitted to engage in the act, and others have reasons to permit and legalize the act. $^{7}$ I assume that one reason to permit a wrongful act is that the consequences are sufficiently beneficial for a victim, who also consents to the act because of these benefits. For an example of such an act, consider a sexist individual who believes women are mentally inferior to men and so, as a result, helps women in need by providing donations to women's shelters. While this man's actions have some wrong-making features, including his sexist intentions and the demeaning nature of his assistance, his actions may still be permissible due to the benefit obtained for the women he assists. At the very least, it is worth considering when such actions may be permissible despite their wrong-making features. This is not to claim that actions are permissible based solely on consequences or that, if an individual acts permissibly, they are not worthy of moral condemnation. Nor do I assume that, if an individual benefits from a permissible act, they must be grateful. Rather, my assumption is merely that benefits can create countervailing reasons for establishing permissibility.

When presenting my argumentation, I shall generally assume that paying minorities to leave has wrong-making features. Intuitively, this seems clear, and I shall present theories that explain this intuition. But though the payments have wrong-making features, the benefits may still constitute a countervailing reason to permit the act. My goal is to establish when this countervailing reason is sufficient to permit the act, and when it is not.

Throughout the article, I will largely remain neutral as to the full range of reasons for why discrimination is wrong. Some argue discrimination is wrong when it excludes individuals, others when it denies opportunities, others when it demeans, and so forth. Some believe, as I do, that discrimination can be wrong for two or more of these reasons, depending on the context. ${ }^{8} \mathrm{My}$ goal is not to prove that any one or more of

\footnotetext{
${ }^{7}$ There may be a distinction between claiming a person is morally permitted to engage in an act, and claiming that others have decisive reasons to permit the act. I shall generally not distinguish between these two understandings of permissible, as nothing in my argument rests on the distinction.

8 Sophia Moreau. 2010. "What is Discrimination?" Philosophy and Public Affairs 38(2), see pages p. 157160; David Benatar. 2012. The Second Sexism: Discrimination Against Men and Boys, Malden, USA and
} 
these reasons explains the wrongness of discrimination. It is to demonstrate that, even when there are multiple reasons to view discrimination as wrong, there remains the competing consideration that victims consent to these payments because they benefit. When this competing consideration is present, a question arises as to whether the discrimination is permissible. It is this question I address.

When I speak of benefits, I speak primarily of monetary goods. I hold these benefits to be of moral significance not merely because victims gain materially, but because of the non-material goods that money can buy, including access to mobility and employment in distant cities, and the self-respect that comes with this employment. When individuals are very disadvantaged, money can also narrow the gap between the worst off and best off, helping individuals access opportunities they otherwise might not obtain, and the means to pay for rent, food, books, toys for one's children, leisure time, and the moment of respite that comes with being handed a large amount of money.

Though I focus on monetary benefits, we might also imagine non-monetary incentives to leave. Minorities might be offered free housing far away, or free scholarships to study in a distant institution. We might imagine an employer who, rather than firing minorities, promotes them to better positions, with offices far away. I mostly put these cases aside. This is largely because, when minorities historically have been paid hard cash to leave, the racist and sexist intentions of the payers have been especially salient, as have the benefits for recipients. As such, the tension between two competing considerations is especially clear.

Though I focus on the puzzle of payments to leave, resolving it can help clarify the scope of wrongful discrimination more generally. By looking at cases where victims of discrimination acquiesce to discriminatory payments - because they benefit - we can better establish whether benefits matter in deciding when differential treatment is decisively impermissible, and should be illegal. Resolving this puzzle can also build

Oxford, UK: Wiley-Blackwell, see page p. 5; Tom Parr and Adam Slavney. 2016. "Harmless Discrimination." Legal Theory (Forthcoming). 
on current debates regarding monetary transactions more generally. It has been argued that certain markets are unethical because they function under unjust background conditions, or reinforce stereotypes, or strengthen objectionable norms. ${ }^{9} \mathrm{I}$ shall show that paying minorities can have these impacts, but consider whether payments ought to still be permitted, given the consent and benefits for minority members.

In describing minority members, I shall mostly focus on ethnic and gender groups, all of whom I shall call "minorities." I will not significantly address discrimination against other groups, such as disabled individuals or senior citizens paid to leave institutions, companies, or buildings. This is for simplicity. If you believe that discrimination against other groups is similar, this is consistent with the argumentation I put forth.

Finally, I put aside cases of structural injustice, where no agent has an explicit intent to exclude. ${ }^{10} \mathrm{I}$ limit myself to cases where the discriminator pays minorities with the motive of encouraging them to leave, because they are valued less. These cases have been overlooked, but are prevalent. Current theories on discrimination do not quite resolve whether such payments are permissible, and how the state should respond.

\section{Four Theories}

To demonstrate why current theories of discrimination cannot establish when paying minorities to leave is impermissible, it is helpful to consider how different theories might respond to the case of the White Citizens Council.

The White Citizen Council was an organization established in the 1950s to keep segregation legal in the American South. They lobbied congressmen, boycotted black-

\footnotetext{
${ }^{9}$ Deborah Satz. 2010. Why Some Things Should Not Be for Sale: The Moral Limits of Markets, New York. Oxford University Press, p 130 and Anne Phillips. 2013. Our Bodies, Whose Property? Princeton: Princeton University Press; Michael Sandel. 2012. What Money Can't Buy: The Moral Limits of Markets, New York: Penguin.

${ }^{10}$ Fred Pincus. 1994. "From Individual to Structural Discrimination," in Fred L. Pincus and Howard J. Ehrlich, eds. Race and Ethnic Conflict, Boulder, CO: Westview, pp. 82-87, 84.
} 
owned businesses, and even produced a children's book that taught heaven was segregated. ${ }^{11}$ By 1962 they failed to keep segregation legal, and so changed their tactics, offering thousands of African-Americans money to leave southern states and move north. The first recipients of this offer were Louis and Dorothy Boyde and their eight children, all living in New Orleans. Louis had recently lost his job after falling ill, and Dorothy was expecting another child. They accepted the Council's $\$ 50$, food, and bus tickets out of town, ${ }^{12}$ arriving in New York City two days later, elated to start a new life with less overt racism, more stability, and greater employment opportunities. ${ }^{13}$ The Council had many goals in sponsoring their migration, but one was to reduce the number of African-Americans in New Orleans. ${ }^{14}$

There are four theories we might raise to establish whether the Council's offer was permissible. The first three theories struggle to establish why paying minorities to leave may be wrong in any sense. I take this as a point against such theories, given the intuitive feeling that something is wrong in the actions of the White Citizens Council. The fourth theory establishes the wrongness of paying minorities to leave, but does not establish if the payments are permissible, given the benefits and consent of the recipients.

\subsection{Other features}

The first theory is not quite a theory, but a claim: The Council's payments were not themselves wrong or impermissible. It was the other features of the case that indicate impermissible actions.

There are three other features of the case, other than payments, which could indicate impermissibility. The council engaged in other racist activities, and there was general racism in New Orleans. Payments, we might suppose, indicate other forms of wrongful discrimination, and are not themselves wrong. Any institution that pays minorities to leave is probably living in a society where minorities cannot attend

\footnotetext{
11 Timothy B Tyson. 2005. Blood Done Sign My Name: A True Story. USA: Random House, p. 182.

12 Webb ibid, 249.

${ }^{13}$ Webb ibid, 249.

${ }^{14}$ Webb ibid, 253.
} 
certain schools, buy certain houses, or walk down the street without fear of being attacked. At the very least, it is a society with widespread implicit biases and structural inequalities, and it is these inequalities alone that are wrong and impermissible to support.

Another possible wrong-making feature is related to the involuntariness of the Boydes' decision. As victims of severe poverty and general racism, they were compelled to accept the free transport and cash. ${ }^{15}$ If ethnic minorities are compelled to leave town, they are victims of forced discrimination. Perhaps it is the forced nature of their departure that disturbs us, rather than the offer of money itself.

Finally, some might argue that the Bodyes were wronged because they were exploited, rather than because they were paid. In general, wrongful exploitation occurs when we enter a transaction with an individual whose rights have been violated, and we benefit off of their rights violations. If a factory owner hires a worker, paying her a piece of bread a day, and the reason she accepts such a low wage is because her land has been stolen, then she is being exploited. ${ }^{16}$ Similarly, if the Boydes' reasons for accepting the $\$ 50$ were because of general discrimination and poverty in New Orleans, they were wrongly exploited. The White Citizens' Council gained from the Boydes' unjust circumstances in the sense that, for a mere $\$ 50$, the Council could encourage African-Americans to leave, satisfying their racist preferences.

\footnotetext{
15 Webb ibid, 249.

${ }^{16}$ This theory of exploitation is slightly different than that raised by others, such as Valdman and Steiner. Both claim that, to wrongfully exploit another person, it must the case that the exploited gain less from the exploiter than some counter-factual state of affairs where the exploited were not vulnerable or had their rights violated. This formulation is problematic. Consider the following example: a starving person agrees to accept a piece of bread to work, but had she not been vulnerable or had her rights violated, she would have accepted nothing at all, and volunteered for the factory. It still seems like exploitation if the woman really is vulnerable or had her rights violated even though, in a counter-factual world where she was not vulnerable or had her rights violated, she would have accepted the same or less payment. She is exploited, I believe, because her reasons now for accepting only a piece of bread is that she is vulnerable or had her rights violated. See Mikhail Valdman, "A Theory of Wrongful Exploitation," Philosophers' Imprint 9(6)(2009):1-14; Hillel Steiner, “A Liberal Theory of Exploitation," Ethics 94(2)(1984):225-241; Hillel Steiner, "Liberalism, Neutrality, and Exploitation," Politics, Philosophy, and Economics 12(4)(2013): 335-344.
} 
I do not believe that these other features of the case - racism in New Orleans, the involuntariness of the consent, or exploitation - can fully explain the intuition that there is something wrong with paying minorities to leave. Imagine the Council consisted of exactly one white supremacist living in a very tolerant city. She spent her days knocking on the doors of ethnic minorities, offering money on the condition that they leave town, and recipients accepted the money without facing any coercion, poverty, or rights violations. Many may feel uneasy about such payments even though they entail no other forms of racism, coercion, or exploitation. Something seems wrong, and a good theory of discrimination will explain why.

\subsection{Harm and Belief-Based Theories}

There are two theories of discrimination that struggle to explain the wrongness of payments to leave, let alone if they are permissible. The first theory claims that discrimination is wrong if it harms its victims. Different theorists claim that different harms are morally relevant. Some claim that discrimination is wrong when it excludes minority members, even if they are not made worse off. ${ }^{17}$ Others claim discrimination is wrong when it disadvantages the worst off in society, ${ }^{18}$ or denies minorities equal opportunities. ${ }^{19}$ Finally, some claim discrimination is wrong when it widens the gap between advantaged and disadvantaged groups. ${ }^{20}$

These Harm-based theories seem to imply, counter-intuitively, that there was nothing wrong with the Council paying the Boydes, because they were not harmed. Though the Boydes left, they were not excluded in the traditional sense. They were never forced to leave, and the money helped them escape a society full of exclusion, and join one with less segregation and far more job opportunities. While it is true that leaving New Orleans was likely a difficult experience, prying them away from the friends, families and home they knew, it also helped them obtain opportunities they preferred to have. Nor did the family just happen to benefit from the Council's

\footnotetext{
${ }^{17}$ Hugh Collins. 2003. “Discrimination, Equality, and Social Inclusion,” Modern Law Review 66(1): 16-43

${ }^{18}$ Lippert-Rasmussen, Kasper. 2006. "The Badness of Discrimination", Ethical Theory and Moral Practice 9: 167-85, 167.

${ }^{19}$ Lippert-Rasmussen 2013, 175 and Segall 2012.

${ }^{20}$ Tarunabh Khaitan. 2015. A Theory of Discrimination Law, Oxford: Oxford University Press.
} 
discriminatory payment scheme, as when a person is denied a job opportunity, moves to another city, and happens to find greater opportunities and advantages in this new city. ${ }^{21}$ The White Citizens' Council specifically intended for AfricanAmericans to benefit from migrating, to persuade them to leave and never come back.

The Boydes, as members of a disadvantaged group, were also never made worse off by the payments, or denied the same opportunities as white residents. Nor did the payments widen the gap between their position and the position of white residents of New Orleans. Precisely the opposite: As they boarded the bus, cash in hand, they were given one extra opportunity that white residents did not have, including very poor residents who preferred funds to leave, but could not access these funds. It seems oddly to fall under the category of affirmative action, which LippertRasmussen argues is a form of justified discrimination. The bus tickets and money, to use his words, closed "the gap between how well-off those who benefit unjustly from discrimination are and how well-off they would be if no discrimination took place henceforth." 22

Harm-based theories similarly struggle to establish the wrongness of other cases involving payments. Today, some attorneys claim that women can receive higher severance pay if they prove they were discriminated against, including in the termination of their contract. ${ }^{23}$ If this is true, some companies may essentially pay women to leave, offering generous severance to women in return for their quiet acquiescence to the termination of their contract. These women may be better off than if they received no extra severance pay, and slightly closer, economically, to their male counterparts. We might even imagine a woman paid to leave a company and made economically better off than if no discrimination had taken place at all, receiving more money than the men received in their salary and severance pay. If we

\footnotetext{
${ }^{21}$ One might think that, if a minority member just happens to benefit from discrimination, but this benefit was not the intent of the discriminator, then the minority member was still wronged. This is an argument raised by Lippert-Rasmussen. See Lippert-Rasmussen 2013, 157.

${ }^{22}$ Lippert-Rasmussen 2006, 160.

${ }^{23}$ Bosin, Andrew S. LLC. "Discrimination and Harassment Claims Could Increase Amount of Severance Offered," downloaded on 20 July 2015 from: http://www.njbusinessattorney.com/articles/discrimination-harassment-claims-increase-severance.html.
} 
intuitively feel there is something wrong about such severance pay, a good theory of discrimination should explain why.

A second set of theories, called "Belief-based theories," can better account for the intuition that something is wrong. These theories view discrimination as wrong when the result of racist or sexist beliefs, regardless of whether victims are excluded or disadvantaged. ${ }^{24}$ The Council had racist intentions when paying blacks to leave, and companies may have sexist intentions when paying women to leave. It is these intentions which are wrong.

Though Belief-based theories explain the wrongness in these types of cases, they cannot explain the wrongness of paying minorities to leave without any racist or sexist intentions. Consider the case, from 2015, involving a Brooklyn landlord paying $\$ 12,000$ to black residents agreeing to vacate their apartments, never paying white residents this money. His interests were financial: an all-white building increased the market value of his property, allowing him to charge more rent. ${ }^{25} \mathrm{He}$ may have had prejudicial beliefs - a recent interview suggests he $\operatorname{did}^{26}$-- but if he did not, his actions still seem disturbing, even if they were motivated solely by financial gain. While it is true that discrimination can be wrong because of racist intentions alone, ${ }^{27}$ it seems that paying minorities to leave is wrong even when there are no racist intentions.

Some may argue that the case of the Brooklyn landlord is a case of racist beliefs. The landlord was responding to the demands of white renters willing to pay more to live in an all-white apartment. These white renters had racist beliefs, or at least objectionable preferences and biases. It is wrong, some argue, to discriminate in

\footnotetext{
${ }^{24}$ Richard Arnson. 2006. “What is Wrongful Discrimination?" San Diego Law Review 43(4):775-807; Larry Alexander. 1992. “What Makes Wrongful Discrimination Wrong?” University of Pennsylvania Law Review 14(1): 149-219.

${ }^{25}$ Importantly, there is no evidence he discriminated in his choice of tenants; he merely encouraged black tenants to leave, while white tenants remained. He could then raise the rent of the vacated apartments, as white residents were willing to pay more money to live in an all-white apartment building.

${ }^{26}$ Gibson 2015.

27 Slavny and Parr ibid.
} 
response to the racist beliefs or biases others, even if the discriminator himself has independent non-objectionable beliefs. ${ }^{28}$

But even if racist beliefs can explain the wrongness of paying minorities to leave, such beliefs do not quite establish whether such payments are impermissible. It is precisely these racist beliefs that contribute to victims' benefiting. If victims' prefer the money to leave than no money at all, perhaps we ought not prevent these payments from transpiring. ${ }^{29}$ To be clear: this is not a criticism of Belief-based accounts, which are intended to establish wrongness, rather than permissibility. Rather, it is to emphasize that, if we wish to establish when payments to leave are impermissible, despite their wrong-making features, we need a distinct theory from Belief-based accounts.

\subsection{Expressive meaning}

The "Expressivist" theory is especially effective at explaining the wrongness of payments but, like Belief-based accounts, also does not establish permissibility.

According to Scanlon and Hellman, both proponents of this general theory, discrimination is wrong because it expresses an offensive ${ }^{30}$ or demeaning ${ }^{31}$ message that minority groups are "not fully human or...of equal moral worth." 32 One can express demeaning messages even if one has no racist or sexist intentions, and even if one is not aware one is offending and demeaning others. If a principal requests that black students and white students sit on opposite sides of the classroom for purely

\footnotetext{
${ }^{28}$ For example, it is wrong to only hire white salespeople to successfully sell to white racist costumers. This is close to the argument raised by David Benatar. See Benatar, ibid, p. 7.

${ }^{29}$ Indeed, Slavney and Parr suggest the general possibility that, even if discrimination is wrong because of the beliefs of the discriminator, discrimination may still be permissible (or not "all-things-considered wrong") if the victim benefits significantly. They raise the example of a racist admissions officer in a lowranking university who hopes to reduce the number of dark-skinned students. Rather than rejecting these applicants, she persuades the admissions team at Oxford to accept them instead. The students are happy with this result. Slavney and Parr conclude that "Sufficiently large benefits may be capable of defeating the wrongness of the discrimination." (p. 12). It is not clear, however, when such large benefits defeat the wrongness, or at least make the discriminatory act morally permissible, and free from state interference.

${ }^{30}$ Thomas Scanlon. 2008. Moral Dimensions: Permissibility, Meaning, Blame. Cambridge, MA.

${ }^{31}$ Hellman 2008 ibid.

${ }^{32}$ Hellman ibid, 35.
} 
aesthetic reasons - and completely unaware of the history of segregation - his classification would be demeaning regardless of his beliefs. ${ }^{33}$

One can even demean someone who is not aware they are being demeaned. ${ }^{34} \mathrm{~A}$ girl with cognitive disabilities may be demeaned if taunted on the playground, even if her impairment means she is not aware she is being taunted. Importantly, one can offend or demean another even if they benefit in some ways. Hellman argues this point using an example of Nelson Mandela in prison on Robin Island. He and black inmates were forced to wear shorts, clothes normally reserved for children. Mandela may have benefited from cooler clothing on such a hot island, but was wronged because he was treated in an infantilizing manner. ${ }^{35}$ We might imagine other actions with a benefit that entail a demeaning message. A woman may be given the opportunity to work in a pornographic film that is violent and degrading towards women. Let us put aside whether such practices are wrong. ${ }^{36}$ It seems clearly wrong to go up to a woman on the street and ask if she would be willing to take part in violent sexual acts in return for money. Offers for extra options can be demeaning even if, in accepting such offers, some women benefit from the money.

There are a number of reasons that offers can be demeaning, even if recipients benefit. One reason is that offers objectify recipients, as in the case of the women above, or because they express a lack of sensitivity to historical injustices, as in the case of the principal segregating children. Beneficial offers can also demean if combined with an endorsement of racism or sexism, such as offering women fewer hours of work out of a belief that women are less capable, but paying them the same salary as men, benefiting them in the process. Discriminatory offers can also demean others when treating them as members of a group, rather than as individuals with their own autonomous decisions, preferences, and talents. Benjamin Eidelson evokes this point with an example of an orchestra director who selects an East-Asian violinist, despite

\footnotetext{
33 ibid, 26. This example was original raised by Paul Brest. See Paul Brest. 1975. Processes of Constitutional Decisionmaking: Cases and Materials. Boston: Little Brown and Company.

${ }^{34}$ Hellman, ibid 27.

${ }^{35}$ Hellman, 27.

${ }^{36}$ Phillips 2013 ibid; Cynthia A. Stark. 1997. "Is Pornography an Action?: The Causal vs. the Conceptual View of Pornography's Harm," Social Theory and Practice 23(2):277-306; Hellman ibid, 42.
} 
her poor performance, because he is influenced by the stereotype that women of EastAsian descent are better at playing the violin. He disrespects her because he treats her as a member of a group, rather than an individual with her own unique character and skills. Such actions are demeaning even if the violinist benefits. ${ }^{37}$

Expressivist accounts seem consistent with the intuition that the White Citizens' Council's actions were in some ways wrong. The Council was treating the Boydes, and all African-Americans in New Orleans, as members of a group, rather than individuals to be judged according to their skills, character, and unique attributes. Because the payments were combined with an endorsement of segregation, the payments also implied a demeaning message: "We do not want you so much, that we are willing to give you money to leave." Indeed, the greater the financial benefit for the victims, the more strongly the discriminator is expressing how much they are willing to sacrifice personal resources to meet their racist preferences. ${ }^{38}$ In this sense, payments are distinct from merely requesting that another person leave, without offering any money at all. The money is constitutive of the message, and so constitutive of the wrong. ${ }^{39}$

When the payer does not endorse racism, the payments can still be demeaning if they evoke a certain meaning derived from historical segregation. Imagine a principal

\footnotetext{
${ }^{37}$ Benjamin Eidelson. 2013. "Treating People as Individuals" in (ed.) Deborah Hellman and Sophia Moreau, Philosophical Foundations of Discrimination Law, Oxford: Oxford University Press. Sometimes, such treatment is not demeaning, or seems less demeaning. If a white man is elected because of his gender and ethnicity, despite poor performance, it does not seem he is demeaned, despite being treated as a member of a group, rather than an individual. It may only be demeaning if the minority group is in some ways disadvantaged, or has been historically disadvantaged. See Tarunabh Khaitan. 2013. "Prelude to a Theory of Discrimination Law," in (ed) Deborah Hellman and Sophia Moreau. Philosophical Foundations of Discrimination Law. Oxford: Oxford University Press, p.145.

${ }^{38}$ Indeed, some argue that, whenever we undermine the dignity of others, we are essentially expressing a certain offensive message. See Tarunagh Khaitan. 2012. "Dignity as an Expressive Norm: Neither Vacuous Nor Panacea," Oxford Journal of Legal Studies 32(1):1-19.

${ }^{39}$ This is not to claim that, whenever an agent pays minorities to leave, they are necessarily demeaning these minorities. We might imagine an anti-racist NGO that provides funds to rescue minority members from a racist society. Their actions may not be demeaning if the NGO makes clear they support equality, and provide money in a way that mitigates any offensive meanings that may arise. They might, for example, provide money alongside lobbying for the end of racism, while making clear that the payments are to help individuals achieve equal opportunity, rather than to reinforce racial separatism. But when payments are provided as an endorsement for racism or sexism, or in a way that evokes an offensive meaning due to historical injustice (as with the principal), then the payments do imply a demeaning message.
} 
paying black students to sit on the right side of the room for aesthetic purposes alone. This seems demeaning due to the historical meaning of such an action, even if the principal does not endorse any form of racism, and even if the black students financially benefit.

The idea that payments can be demeaning may be consistent with some Harm-based accounts. If payments are demeaning, they also socially exclude ${ }^{40}$ in the sense that individuals are told how little they are valued in society. If such social exclusion is a harm that cannot be traded away for money, ${ }^{41}$ then payments are harmful even if they involve monetary benefits. We might also suppose that, if payments are demeaning, they also undermine equality of opportunity, in the sense that individuals no longer have the opportunity to be free from the demeaning message implied by the payments. ${ }^{42}$ Similarly, if demeaning others harms them, and harming the worst off is what makes discrimination wrong, ${ }^{43}$ then we can view demeaning payments as wrong in this sense. In other words, some Harm-based accounts, like Expressivist accounts, can view demeaning others as wrong regardless of benefits.

Even if payments are wrong, this does not establish when payments are permissible. As Hellman herself notes, her theory of discrimination does not "say when the wrongfulness of [discrimination] may be overridden by other considerations." 44 Other considerations may include the benefits minorities gain, and their acquiescence in light of these benefits. Were the state to legally ban payments, this would deny minority members access to money they could otherwise obtain, and which some wish to obtain. While the demeaning character of discrimination constitutes its wrong, it remains unclear if the beneficial character of discrimination can establish its permissibility.

\footnotetext{
${ }^{40}$ Collins ibid.

${ }^{41}$ Not all Harm-based theorists support this conclusion, but this is implied by Collins' harm-based account. See Collins ibid: 25.

${ }^{42}$ Segall ibid.

${ }^{43}$ Lippert-Rasmussen 2006 ibid,167.

${ }^{44}$ Hellman ibid, 31.
} 
Some might argue that benefits for victims - even significant ones - do not constitute a competing moral consideration, and so ought not make wrongful discrimination permissible. Hellman and Yuracko both discuss a case that evokes this intuition, involving a casino that forced female workers to wear makeup, forbidding male employees from doing so. For different reasons, Hellman and Yuracko both conclude that the casino wrongfully discriminated against the women..$^{45}$ This case is interesting, I believe, partly because the employees gained a salary, were not forced to work at the casino, and possibly benefited compared to alternative forms of employment. Despite these benefits, I still feel the women were treated in an impermissible manner, and the weight of the benefit seems insignificant.

Even if this is true, the women were not benefiting from the discrimination itself; they would still gain a salary in a world where employers stopped requiring women to wear makeup, assuming the casino would retain its customers when women ceased wearing makeup. As such, if the government banned sexist dress codes in casinos, it is unlikely women would be worse off. This is not the case with payments to leave: minorities would lose money if this type of discrimination were banned, because the discrimination is precisely what entails paying individuals money.

Some might argue that, even if minorities prefer the payments, such preferences are not strong reasons to permit otherwise wrongful discrimination. This is because, more generally, preferences hold little weight in establishing the permissibility of wrongful discrimination. If most women in a country prefer that all women be banned from voting, their preferences seem less important than our hope that all women are given the freedom to vote. But there is an important distinction between preferences for forced exclusion and preferences for voluntary incentives. Were women to oppose the vote, and insist they were not demeaned, we might claim their beliefs were the result of non-autonomously developed preferences, given that they were denied the vote their whole lives, possibly excluded from public life more

\footnotetext{
${ }^{45}$ Hellman ibid, 46 and Kimberly Yuracko. 2006. "Sameness, Subordination, and Perfectionism: Towards a More Complete Theory of Employment Discrimination Law," San Diego Law Review 43: 857-897.
} 
generally ${ }^{46}$ We cannot quite say this about the Boydes: The money really did make their lives go better. It would be odd to claim that they were somehow mistaken about their own beliefs, the way a subjugated individual may falsely believe they are not subjugated.

More importantly, when minority members support forced discrimination - such as women supporting banning female voting - they are denying other women the vote, including women who want to vote. At the very least, they are undermining the autonomy of other women, denying them the right to vote if they ever wish to vote. The same cannot necessarily be said about the Boydes. When they boarded the bus, nobody else was forced onto the bus. It was their private choice alone.

Of course, it was not quite their private choice alone. The Council's actions, and the Boyde's acquiescence to leave, may have harmed others in society. This is a possibility I shall now address.

\section{Conditions for establishing impermissibility}

Paying minorities to leave should be deemed impermissible if at least one of two conditions is met: first, others are harmed by the payments and, second, recipients fail to consent to the payments.

\subsection{Third-party Harm}

In general, harm towards third parties is at times a justified reason for states to ban discrimination. Lippert-Rasmussen provides the example of a natural disaster with sectarian charities actively helping their own congregants, though not others. Though the act of giving to one's own religious sect does not necessarily demean anyone, and harms nobody compared to giving nothing at all, a state may justifiably pass laws to require that all organizations help all people in need, to prevent sectarian strife

\footnotetext{
${ }^{46}$ For a discussion on autonomously-developed preferences, see Richard Arneson. 1994. "Autonomy and Preference Formation," in (ed.) Jules L. Coleman and Allen Buchanan, In Harms Way: Essays in Honor of Joel Feinberg. New York: Cambridge University Press: 42-75; and Natalie Stoljar. 2000. "Autonomy and the Feminist Intuition" in (ed) C. MacKenzie and N. Stoljar, Relational Autonomy, ed. Oxford: Oxford University Press, 94 -111.
} 
during an especially precarious period. ${ }^{47}$ Similarly, many market transactions should possibly be illegal, Deborah Satz writes, because of how they impact others. In her example, a reason to ban surrogacy services is that it reinforces stereotypes of women as baby-making machines, and this may harm other women..$^{48}$ This would be true even if the surrogates themselves benefit from a given transaction.

A similar line of reasoning can be applied in paying minorities to leave. Payments, even if beneficial towards recipients, can harm others.

One potential harm is the increase in implicit bias against other minority members. If the public is unaware that there is an exchange of payments, they may assume that minorities are less willing to stay. This may reinforce stereotypes that certain groups are less willing or capable of staying. Were a woman to retire earlier because she was given greater severance pay, and did not publicize this higher severance pay, others may believe she was retiring early because she wanted to work less than men, when in fact she wanted to retire early because she was paid to leave more than men. Her leaving may reinforce associations between being a woman and not willing to work as long.

When payments are publically announced, rather than kept secret, this may increase the legitimacy of racist and sexist views. Today, there is often a taboo against holding racist and sexist preferences. If individuals publically announce their preferences by offering money to leave, this may normalize such preferences. Payments may also reinforce attitudes of disrespect more generally, normalizing demeaning expressions, effecting those who never received offers of payments, or who would rather they never existed at all.

Finally, payments can undermine efforts to counteract historical segregation, often associated with serious inequalities and injustices. If payments encourage ethnicities to voluntarily live in separate neighbourhoods, individuals may be less likely to

\footnotetext{
${ }^{47}$ Lippert-Rasmussen 2013 ibid, 269.

${ }^{48}$ Satz ibid, 130.
} 
interact with members of other ethnic groups, which may undermine mutual cooperation, often essential for community-building and mutual respect. ${ }^{49}$ In general, encouraging segregation, even voluntary segregation, may increase disparities along ethnic lines, contributing to unequal education, employment, and housing. Because of these harms, governments have strived to increase integration by encouraging citizens to voluntary live in integrated neighbourhoods. ${ }^{50}$ If a landlord pays minorities to move elsewhere, the landlord's actions mitigate such efforts.

Even when payments do not cause the above consequences, payments may still cause harm. If Hellman is correct that discrimination is wrong when it demeans, we might claim that discrimination can be wrong because it demeans third parties, even if they are never directly discriminated against. When a racist agent pays minorities to leave, they are not only expressing that they value certain individuals less than others. They are expressing that they value certain characteristics less than others, and this demeans others who hold these same characteristics. Imagine that the CEO of a company pays an anchorwoman to retire earlier than men, though never paying other female employees to retire earlier than men. These other employees understand that a characteristic they hold - their gender - is valued less even if, due to their particular position in the company, they are still valued. Similarly, other AfricanAmericans in Brooklyn, never paid to leave their particular buildings, are exposed to the general message that their ethnicity is viewed as indicative of their lesser worth. Other African-American residents of Brooklyn are demeaned, regardless of whether they personally experience an increase in racism or racial separatism from the payments. Importantly, they are demeaned without any corresponding benefit, given that they were never personally paid to leave. They were thus treated in an all-thingsconsidered impermissible manner.

Indeed, the more public the payments are, the more public the general message, impacting both those offered and never offered money to leave. This is because the

\footnotetext{
${ }^{49}$ Elizabeth Anderson. 2010. The Imperative of Integration. Princeton: Princeton University Press, 2.

${ }^{50}$ Ronald Sundstrom. 2013. “Commentary on Elizabeth Anderson's The Imperative of Integration." Symposia on Gender, Race, and Philosophy 9(2):2.
} 
payments imply the following message: "I am willing to pay money to encourage members of this group to leave." Other members of the group understand that, in a close possible world - a world where they lived in a particular building, or held a different position in a company - they, too, would be unwanted. And even when the payer is not endorsing a racist or sexist message-such as a landlord whose motives are purely financial - payments can still demean others. As noted in the last section, payments are partly demeaning because they express the payer's failure to recognize minority members as individuals, judging them based on their ethnicity, gender, sexuality, or other characteristics. ${ }^{51}$ Other minority members may understand that characteristics they posses are viewed as indicative of who they are, treated as members of a group rather than as autonomous individuals.

The above argument focuses on the public nature of the payments, as a public expression of disrespect towards all members of a minority group. I believe that even private payments could demean third parties. This is because discrimination can be demeaning towards individuals who are not aware of the discrimination, and so never personally offended. Return, again, to the case of the girl with cognitive disabilities who is taunted on the playground, demeaned despite being unaware of the meaning of the taunting message, and so never personally offended. If one can be demeaned from a message one never comprehends, perhaps third parties can be demeaned from a message they never hear. We often use the word "demeaning" in this way, as when we say women are demeaned by violent pornography, including those who have never heard of this pornography. Just as one can be demeaned by a phenomenon they never hear of, minorities can be demeaned by payments they are not aware of.

Whether one accepts this claim depends on whether one accepts it is possible to wrong someone who is not aware they are wronged, and experiences no reduction in welfare. Putting this debate aside, we can at least conclude that public payments constitute a clear expressive harm towards third parties. These third parties have

\footnotetext{
${ }^{51}$ Eidelson 2013 ibid.
} 
been wronged without any corresponding benefits. As such, they have been impermissibly wronged.

This conclusion may have implications for some forms of indirect payments. Imagine a Brooklyn landlord - who I call Adam - pays another landlord - who I call Betty money to lower her rent dramatically, luring Adam's black tenants to Betty's nowcheaper apartments, leaving only white tenants behind in Adam's building, increasing the value of his property. ${ }^{52}$ Even if this benefits the tenants who move, the transfer of money from Adam to Betty still sends a demeaning message towards other minority members never lured away from Adam's apartments. These other minority members understand how much Adam is willing to pay to fulfil the racist housing preferences of white tenants. They are exposed to a demeaning message without any corresponding benefit. Adam's payments also contribute to harmful consequences if, in taking part in this payment scheme, he contributes towards racial separateness and normalizes racist preferences. Like with direct payments to leave, such actions may be morally impermissible due to harms towards third parties.

This case, of course, is distinct from direct payments: Adam's actions are not directly discriminatory, as he is sending money to Betty, and not to minorities alone. Nonetheless, we might still view such cases in a similar light as directly paying minorities to leave, given the effects on others.

While the above examples all take place domestically, we might imagine governments paying ethnic minorities to leave the territory of the state. As noted in the introduction to this article, in 2010 the British Nationalist Party proposed paying $\$ 78,000$ to every non-white asylum seeker who agreed to repatriate from the UK. ${ }^{53}$ More recently, Israel has begun providing $\$ 3,500$ to African migrants agreeing to repatriate or move to another country, denying similar payments to non-African migrants of comparable legal status. ${ }^{54}$

\footnotetext{
${ }^{52}$ A special thanks to a reviewer from Politics, Philosophy and Economics for raising this example.

${ }^{53}$ Smith ibid.

${ }^{54}$ Mollie Gerver. Forthcoming. 'Paying Refugees to Leave.' Political Studies.
} 
Some might argue that such payments in immigration control are distinct from domestic payments. If states have a sovereign right to control their borders - a commonly held assumption ${ }^{55}$ - they may have a sovereign right to pay non-citizen minorities to leave. More generally, principles of justice in the international arena are distinct from principles of justice domestically, and so we cannot simply apply my analysis of domestic payments to the case of immigration control.

But paying non-citizen minorities to emigrate may be a domestic injustice if payments demean citizens of the same minority. These citizens understand that a characteristic they hold - their ethnicity - is partly indicative of their worth in the eyes of their government, even if they are ultimately accepted because of their citizenship. Christopher Wellman, a strong proponent of states' right to exclude immigrants, raises a similar argument. States, he concludes, have a right to control their borders to prioritize citizens' interests. If so, states are not permitted to deny visas based on ethnicity if this sets back citizens' interests. Such policies set back citizens' interests by deeply offending citizens of the same ethnicity. Were the state to ban all non-White immigrants, for example, this would deeply offend non-White citizens, and so would be impermissible on grounds of domestic justice. ${ }^{56}$ Building on Wellman's argument, we can conclude that, even if states have a prima facie right to control immigration, including the right to pay unwanted migrants to leave, they do not have the right to pay only unwanted ethnic minorities to leave. At the very least, states have weighty reasons to refrain from such policies, given the effects on their own citizens.

In the case of both domestic payments, as with the Boydes, and international payments, as with immigration, I do not believe that third parties are always significantly harmed or demeaned. Payments may demean others less if they only occur privately - at least, this is a possibility I leave open - and payments needn't reinforce racial separatism or bias if few accept the payments. If the landlord in

\footnotetext{
${ }^{55}$ David Miller. 2005. "Immigration: The Case for Its Limits" in (ed.) A. Cohen and C. Wellman. Contemporary Debates in Applied Ethics, Malden, MA: Blackwell Publishing: 193-206; Christopher Heath Wellman. 2008. "Immigration and Freedom of Association," Ethics 119: 109-141.

${ }^{56}$ Wellman ibid. Similar arguments have been raised by Miller. See Miller ibid.
} 
Brooklyn hadn't advertised his actions, and if his actions were one-off, we might conclude that only those directly given money were significantly demeaned, and the payments should possibly remain legal, given the consent and benefits for the recipients. But given the public nature of the landlord's offer, and the possibility that such offers are pervasive, these payments are morally impermissible because they wrong others who experience no benefit. A similar claim can be made regarding the White Citizens' Council. It offered thousands of African-Americans payments, possibly reinforcing the outside status of blacks in New Orleans, and demeaning other black residents who understood just how much they were not wanted.

\subsection{Lack of Consent}

Even when there is no clear demeaning message to others, and when payments do not reinforce bias and racial separatism, payments are still impermissible if recipients have not consented to the payments.

There are two groups who may fail to consent.

One group is comprised of those who reject the payment offer, and have been forcibly exposed to the demeaning offer against their will, with no corresponding benefit. Offering women greater severance pay to leave, or offering black families funds to relocate, is clearly impermissible when the vast majority of those given the offer reject the offer, even if no third parties are harmed. This is not to claim we should determine permissibility based on preferences alone. I merely claim that, if the vast majority reject the offer, there is no conflict between their preferences and the wrongness of demeaning treatment. Their preferences have not been met, and they have been demeaned. ${ }^{57}$ As such, the offers are impermissible.

The second non-consenting group is comprised of individuals who accept an offer, but only because it was offered. Given the choice, they would never have wanted the

\footnotetext{
${ }^{57}$ There is similarly no conflict between benefits for minorities and the demeaning nature of the offer; the minorities have not benefited because they have rejected the offer, and they are still demeaned by the offer itself.
} 
offer to begin with. ${ }^{58}$ This may occur when individuals feel that, once a demeaning offer is on the table, the expressive meaning has already been conveyed, and so they may as well accept the money and leave. Individuals may also accept an offer to be polite, or to avoid creating tension, while still wishing the offer were never posed. ${ }^{59}$ As with the first group, their preferences have not been met and they have been demeaned. This may have occurred with the case of the Brooklyn tenants. They may have accepted money because they preferred leaving than living under a racist landlord, and they may have become aware of his racism precisely because of the money he offered. These tenants may have felt that, given the choice, they would have been happier had they never been offered the money at all.

While more empirical research is necessary to establish whether the tenants preferred no offer at all, a recent case from Israel exemplifies such non-consent. In 2015 a woman named Ms. Rabinowitz was seated on an El-Al flight near an ultra-Orthodox man. The man preferred to sit next to men, and told this to a flight attendant, who then asked Ms. Rabinowitz if she would like a better seat near First Class. Ms. Rabinowitz consented, but wished she were never offered the better seat, later suing the airline for wrongful discrimination..$^{60}$ Regardless of whether this is truly a case of wrongful discrimination, it demonstrates that one can consent to an offer without consenting to being given the offer. If an individual has not consented to being given the offer, then she has not voluntarily experienced the offer. She also does not subjectively feel she is benefiting compared to a world where the offer was never posed. In this sense, her experience is similar to discrimination involving a disadvantage against one's will. Even if one believes that a truly consensual and

\footnotetext{
${ }^{58}$ As David Velleman puts it: "Preferring to accept an invitation is consistent with wishing you had never received it." J. David Velleman. 1992. "Against the Right to Die," Journal of Medicine and Philosophy 17(6): 672. More generally, it can be rational to consent to an offer, but also rational to prefer the offer never be available at all. See Thomas Schelling, The Strategy of Conflict. Cambridge: Harvard University Press 1960.

${ }^{59}$ Velleman raises similar arguments in the context of euthanasia. One reason that states ought not to grant the right to euthanasia is that, once a patient has the option, they may feel pressure to accept it. More generally, we often would be better off without an offer even if we would consent to an offer once it was given. For example, in a country where dueling is legal, individuals may consent to duel to save their honor; but many would prefer to never have the option to duel, to avoid being in a position where they need to reject a duel, and lose their honor. Velleman ibid, 676.

${ }^{60}$ Isabel Kershner. 2016. "She Was Asked to Switch Seats. Now She's Charging El Al With Sexism." New York Times 26/2.
} 
substantial benefit can deem an act permissible, no such consent or benefit arises if an individual has not consented to being offered payments to leave.

Some may claim that, even if the vast majority of minority members do not want the offer, the offer should still be permitted if no third parties are harmed or demeaned. If minorities are never told about the offer, all will never be able to accept the offer, including those who want it. Importantly, we cannot know if an individual would have consented to being given the offer unless they are asked, "Do you want me to offer you money to leave?" and this question would be tantamount to an offer. To address this concern, we may wish to distinguish between the ways in which offers are posed. Very public advertisements on billboards, and very intrusive offers on the street, may be more demeaning towards those who do not want the offers compared to private offers. As such, if payments should ever be permitted, offers should be limited to discretely advertised announcements, similar to the types of advertisements for pornography, or for hiring actors for pornographic films. Some may argue that minorities have still not consented to being exposed to discrete advertisements, and minorities can be demeaned by hidden advertisements they are unaware of, as I argued above. If this is true, all offers should be unpermitted.

The above domestic cases are very different than immigration cases, where the state pays non-citizen minorities to leave a country. Assuming citizens are not harmed or demeaned, some might claim that payments are permissible even if the migrants have not consented. This is because non-citizens are owed less than citizens, and because states have a sovereign right to control their borders even without the consent of would-be immigrants. Indeed, even those who support open borders might hold that states are permitted to pay minorities to leave.

Even if one holds that states are permitted to control immigration by paying noncitizens to leave, we may still reach a modest conclusion: the benefits for migrants in being paid to leave, and the consent they provide in leaving, is not a relevant consideration if these migrants feel their lives would be better had they never been offered money at all. As such, states cannot justify their actions by appealing to the 
benefits for migrants and the consent they gave. This leaves open the possibility of other justifications for permitting payments, such as states' sovereign right to control their territory.

\section{Outlawing payments}

The above argumentation suggests that outlawing payments may be justified if third parties are harmed, or recipients have failed to consent. Let us now consider when, precisely, the state should intervene.

In cases where minority members have not consented to the payment offers, they are victims of wrongful discrimination involving no countervailing considerations. They have not consented, nor do they feel they are benefiting compared to a world with no offer at all. If they are sufficiently demeaned and excluded, the offers should be outlawed, and the recipients compensated. It would be comparable to sexual harassment cases, where one person offers another a demeaning and explicit offer they do not want, such as an employer, landlord, or organization approaching a woman and offering her money to perform a sexual act.

A serious dilemma arises when individuals consent to the offer, and genuinely feel they are better off for its existence, but their accepting the offer harms third parties, increasing racial separatism, bias, and demeaning expressions.

In such cases, there are two sets of competing considerations. On the one hand, outlawing payments to leave is necessary for society to obtain a range of non-material and material goods, including greater respect and integration. Just as the state is justified in outlawing the trade of polluting vehicles to help improve air quality, the state is justified in banning payments to protect minority rights. Some goods must be protected, and cannot be replaced with material gains for some members of society. ${ }^{61}$

\footnotetext{
${ }^{61}$ Collins ibid, 25.
} 
On the other hand, some minorities may oppose banning payments to leave, as this forces them to sacrifice potential profits, denying them much-needed funds for the sake of the greater good. Were the government to prevent minority members from accepting payments, perhaps the government would be using them as a means for a societal aim.

We may express these two competing considerations as a tension between individual and group rights. Individual minority members may feel they have a right to engage in a private transaction. Society as a whole, and groups of minorities who oppose payments, may feel they have a right to stop such transactions, given the harm they cause.

Such a tension is common in other cases of discrimination. A paradigmatic example, and which may help us establish when payments should be banned, is the 1991 case involving Manuel Wackenheim, a man with dwarfism who would take part in a sport called "dwarf throwing." This activity involved large men throwing Mr. Wackenheim large distances for entertainment, paying him a steady income to participate. ${ }^{62}$ In 1991 the French Ministry of Interior stated that dwarf-throwing ought to be banned, a decision later upheld by the Council of State, and in 2002 supported by the United Nations Human Rights Committee. Like with payments to leave, Mr. Wackenheim benefited from partaking in "dwarf throwing," but in taking part in this activity possibly demeaned others with dwarfism, and possibly reinforced negative stereotypes and implicit biases. Mr. Wackeneheim felt that it was wrong to deny him his occupation for the greater good of society, as this would be demeaning towards him, denying him employment and a sufficient standard of life for the sake of societal aims. ${ }^{63}$

In general, debates on affirmative action entail a related tension between individual and group rights. There are some who argue that parliaments and the civil service

\footnotetext{
${ }^{62} \mathrm{He}$ always wore a sturdy helmet and protective gear, so there was no significant risk to his physical safety.

${ }_{63}$ Manuel Wackenheim V France, Communication No 854/1999, U.N. Doc CCPR/C/75/854/1999(2002)
} 
ought to represent the makeup of society, and that such representation has intrinsic value, and so affirmative action just. ${ }^{64}$ Such policies may come at the expense of individual members of the majority who, had it not been for the affirmative action, would have been hired. ${ }^{65}$ Similarly, some might deem it impermissible for the government to force private companies to institute affirmative action, such as requiring that $50 \%$ of private executives be women or minorities. Such a policy might entail unjust government imposition on individual liberties. As with payments to leave, establishing a just policy requires weighing the rights of individuals against the rights of groups.

While the tension between individuals and groups can never be fully resolved, a step in the right direction would be to adopt a principle of proportionality. This principle, in general, holds that the state is permitted to use coercion against an individual so long as this does not cause the individual to experience a reduction in basic goods, and so long as the coercion helps others obtain basic goods. Basic goods, I assume, include necessities for survival, an adequate range of options, and freedom from demeaning, sexist, and racist treatment. ${ }^{66}$ In the case of Mr. Wackenheim, we might conclude that the proportionality condition would be met if Mr. Wackenheim had access to an adequate range of jobs besides dwarf-throwing, and if banning the sport would significantly help others obtain freedom from demeaning, sexist, and racist treatment. Similarly, paying minorities to leave should be banned if this ban does not cause a reduction in basic goods for those denied the payments, and if the ban significantly helps other members of disadvantaged groups obtain basic goods.

In the case of the Boydes, I believe the proportionality condition was not met. If the US government was unwilling or unable to assist the Boydes obtain a basic living

\footnotetext{
${ }^{64}$ Anne Phillipps raises this possibility when she writes, "the gender and ethnic composition of any body of representatives is an important measure of whether that body is indeed 'representative'; and that when there are considerable differences of experience attached to being male or female, white or black, in an ethnic-majority or ethnic minority, these differences should be reflected in any decision-making body." Anne Phillips. 2004. “Defending Equality of Outcome." Journal of Political Philosophy 12(1): 1-19, 9.

${ }^{65}$ Morris Abrams. 1986. "Affirmative Action: Fair Shakers and Social Engineers." Harvard Law Review 99(6):1312-1326.

${ }^{66}$ Khaitan 2015 ibid, especially “The Duty Bearers”, p. 195-214.
} 
income in New Orleans, then preventing them from accessing the Council's funds would place an unfair burden on the family. At the very least, a dilemma remains as to the best course of action. In other cases the proportionality condition is met. If a company is providing greater severance pay to women to retire early, and this demeans or harms other women, the state ought to intervene to prevent such payments, as women in this company could continue to access sufficient employment and severance pay if they stayed. In cases like that of the Brooklyn landlord, more research is necessary to understand how urgent the funds were for the tenants who left. If they genuinely could not access basic necessities without the payments, including food and shelter, we might suppose that blocking the transaction would be unfair to the tenants. But if they could access an adequate range of options without the money, it would be justified for the state to ban such discriminatory payments.

The above does not imply that, when minorities are dependent on payments to access basic goods, the state should simply look the other way. The state has a duty to ensure that basic goods can be accessed in ways other than payments to leave. But if the state is unable or unwilling to provide such alternatives, then they have weighty reasons to permit the payments.

This still leaves open the question of how, precisely, the state should intervene.

One option would be to fine those who partake in such transactions. Just as the state fines citizens who sell polluting vehicles and illegal weapons, because such transactions create negative externalities, the state should fine those who pay and accept money to leave, because such payments create negative externalities for other minority members. But unlike the sale of a polluting vehicles or weapons, some may feel it wrong to hold minorities liable for accepting funds. If they are forced to return the money, or pay a fine, then they are victims of demeaning treatment from the offer, without any corresponding benefit. An alternative to forcing recipients to return money would be to view the money as a type of compensation for the demeaning treatment they faced. 
Unfortunately, allowing recipients to keep the money also encourages future transactions that reinforce biases, racialism separatism, and demeaning messages towards others. An alternative policy would be to require that the discriminator compensate the state. This may be enough to dissuade agents from offering payments in the future. This compensation to the state, in turn, can be used to combat sexism, racism, and biases that arise from the existence of the payments.

\section{Conclusion}

Many minority members would prefer to accept payments to leave, than to face continued discrimination where they are, unable to find a job or apartment, or interact with others as equals. Others wish to leave not because they face widespread discrimination, but because they hope to find better opportunities elsewhere, far easier if they receive payments. While such payments may seem intolerable, they help minorities escape intolerance, or start their life anew, making it easier to resettle, find a job, and integrate into a new neighbourhood, company, or city. And while such payments are demeaning, they place resources into the hands of the demeaned, helping ensure their exit is smoother than it otherwise would be, at times enriching them more than if no discrimination took place at all.

To consider when such payments are impermissible, it is not enough to consider if individuals are demeaned or harmed, given the tremendous benefits they can accrue. We must appeal to other considerations, the first relating to third-party harm. Payments are impermissible if they harm minority members never offered assistance to leave. Such harm may arise if payments reinforce biases, contribute to inequality, or demean others never paid. These other minority members understand that, in a very close possible world, they too would be encouraged to leave, given extra cash, severance pay, or a free bus ticket to a distant city, because their physical presence is not welcome.

Even if no third parties are harmed or demeaned, payments are impermissible if recipients wished they had never been offered money at all, and are only accepting 
the money because it was offered. Such individuals have been exposed to a demeaning choice they prefer not to have, and so are not benefiting compared to no payments at all.

In establishing how the state should intervene, we will ultimately face a dilemma. In outlawing payments to leave, states will be promoting greater tolerance and integration for society by sacrificing the interests of minority members who wish to accept money to leave. We ought, I believe, to adopt a principle of proportionality, and refrain from preventing payments when minority members are dependent on them for basic goods. In adopting this approach, states should still strive to ensure individuals are not dependent on such payments for basic goods. And when payments do not protect basic goods, states ought to intervene and prevent such transactions, due to the harms they cause others.

Accounting for such harms is essential for establishing a more complete theory of discrimination. It is true that the Boydes preferred to leave New Orleans, feeling \$50 and a bus ticket provided more opportunities then staying where they were. Nonetheless, we ought to shift our gaze away from them, and onto the status of other minority members. In doing so, we can consider a broader array of people and outcomes, better determining when discrimination is impermissible and when state intervention is justified. 